\title{
PENGARUH BAURAN PEMASARAN TERHADAP KEPUTUSAN WISATAWAN UNTUK MENGUNJUNGI SENDRATARI RAMAYANA PRAMBANAN DI PRAMBANAN
}

\author{
Ismiyati \\ PT.Taman Wisata Candi Borobudur, Prambanan \\ \& Ratu Boko (Persero) Yogyakarta \\ Email: ismiyati@gmail.com
}

\begin{abstract}
Abstrak
Kekayaan alam serta keindahan Indonesia merupakan modal yang luar biasa. Keberadaan objek wisata yang tersebar, tidak lepas dari promosi untuk lebih dikenal oleh masyarakat / pengunjung. Dan dalam pemilihan objek wisata tentunya tidak lepas dari faktor yang mempengaruhi keputusan pengunjungnya.Sektor pariwisata merupakan salah satu prioritas pengembangannya yang keberadaannya diharapkan dapat memberikan pengaruh positif bagi kegiatan lainnya. Keberhasilan suatu kegiatan pariwisata sangat ditentukan oleh tingkat kualitas pelayanan yang diberikan kepada wisatawan dan faktor - faktor pendukungnya, hal ini akan berdampak kepada keputusan wisatawan berkunjung kepada tempat wisata tersebut. Bauran pemasaran jasa mempunyai pengaruh dalam menentukan suatu keberhasilan strategi pemasaran. Penelitian ini bertujuan untuk mengkaji pengaruh dari bauran pemasaran terhadap keputusan wisatawan untukmengunjungi Sendratari Ramayana

Prambanan di Prambanan dengan sampel yang digunakan dalam penelitian ini sejumlah 100 orang responden pengunjung Sendratari Ramayana Prambanan dengan alat analisis yang digunakan adalah regresi linier berganda yang didalamnya terdapat uji Kuesioner ( validitas dan reliabilitas), Uji Asumsi Klasik ( normalitas, multikolinearitas, autokorelasi dan heterokedastisitas ), Uji Regresi Linier Berganda ,Uji Hipotesis (Uji t dan f) dan Uji Koefisien Determinasi. Hasil analisis regresi linier berganda diperoleh hasil bahwa faktor yang paling mempengaruhi keputusan berkunjung adalah promosi dengan nilai koefisien regresi 0,515. dan berpengaruh positif dan signifikan. Tempat, produk menjadi faktor kedua dan ketiga sebesar 0,491 dan 0,346 yang mempengaruhi keputusan wisatawan Sedangkan Harga tidak memiliki pengaruh positif dengan nilai koefisien regresi -0,114. Secara simultan Produk,Harga,Promosi dan Tempat berpengaruh pada keputusan wisatawan dan dalam pengujian koefisien determinasi keempat variabel diatas dapat dapat menerangkan variabel $Y$ sebesar $52,5 \%$.
\end{abstract}

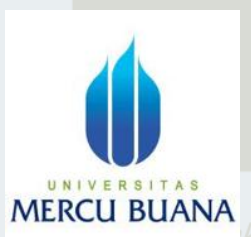

Jurnal Perilaku Dan Strategi bisnis

Vol. 4 No.1, 2016

Hal. $60-71$

Kata kunci: Produk, Harga,Promosi, Tempat, dan Keputusan Wisatawan.

\section{PENDAHULUAN}

Indonesia merupakan Negara kepulauan yang memiliki tujuan pariwisata yang beraneka ragam di dalamnya. Pariwisata di Indonesia sangat beragam dan memiliki pemandangan yang sangat indah, ragam budaya yang kaya didukung dengan keramahan masyarakat Indonesia, tak heran jika banyak turis domestik maupun mancanegara datang ke Indonesia untuk berwisata dan membelanjakan uang mereka atau untuk berekreasi. Keberadaan objek 
wisata yang tersebar, tidak lepas dari promosi untuk lebih dikenal oleh masyarakat / pengunjung. Dan dalam pemilihan objek wisata tentunya tidak lepas dari faktor yang mempengaruhi keputusan pengunjungnya. Keputusan Perilaku Konsumen merupakan suatu tindakan-tindakan yang dilakukan oleh individu, kelompok atau organisasi yang berhubungan dengan proses pengambilan keputusan dalam mendapatkan, dan menggunakan barang-barang atau jasa ekonomi yang dapat dipengaruhi oleh lingkungan (Mangkunegara;2009) Objek dan daya tarik wisata (ODTW) tersebar diseluruh penjuru tanah air. Diantaranya di Daerah Istimewa Yogyakarta (DIY). Yogyakarta adalah salah satu tujuan wisata yang merupakan kota budaya dengan ciri khas masyarakat yang ramah, budaya yang beraneka ragam, keunikan alam serta sarana dan prasarana yang memadahi. Candi Prambanan adalah salah satu objek wisata yang ada di Daerah Istimewa Yogyakarta dan menjadi daya tarik Kota Yogyakarta. Dan visualisasi dari relief yang tertulis di dinding Candi Prambanan terciptalah sebuah atraksi wisata yaitu Sendratari Ramayana. Sendratari Ramayana kisahnya klasik dikenal luas oleh dunia internasional serta nilai - nilai ajaran yang universal yang mengisahkan perjuangan yang tak mengenal akhir antara kebenarankeadilan (dicerminkan oleh tokoh Rama-Shinta) melawan kejahatan - keangkaramurkaan (dicerminkan oleh tokoh Rahwana). Ramayana telah dikenal dan digemari nenek moyang kita sejak abad ke-9. Sementara di kawasan Asia Tenggara lainya seperti Burma, Thailand, Laos, Kamboja, dan Malaysia Ramayana sudah dikenal sejak kurun waktu yang lebih tua yaitu abad pertama Masehi (Moehkardi;2011). Sehingga Sendratari Ramayana merupakan warisan budaya yang adiluhung yang harus tetap dijaga dan dilestarikan.

Variabel-variabel yang dapat dikendalikan atau dikontrol dalam rangka usaha untuk mempengaruhi wisatawan datang berkunjung pada suatu daerah tujuan wisata (DTW) secara populer dikenal dengan $4 \mathrm{P}$ masing-masing: Product, Price, Place, dan Promotion. Supaya usaha kegiatan pemasaran berjalan dengan baik, pertama-tama produk yang hendak ditawarkan harus sesuai dengan selera pasar atau dalam bahasa pemasaran dikenal sesuai dengan kebutuhan (needs) dan keinginan (wants) target pasar yang dituju.

Produk (product) untuk dapat dipasarkan apabila memiliki kualitas yang baik, keamaan yang teruji, useful atau mudah digunakan, dan menarik (eye catching). Untuk itu diperlukan pengembangan produk (product development) yang sesuai dengan selera target pasar sebagai hasil dari riset pemasaran yang dilakukan, kemudian diberi harga, didistribusikan ke tempat-tempat produk semacam itu dijual dan pada saat yang sama dikomunikasikan atau dipromosikan kepada calon pembeli, dalam hal ini adalah calon wisatawan.

Bauran pemasaran 4P yang terdiri dari produk (product), harga (price), tempat (place) dan promosi (promotion) merupakan alat yang dapat digunakan untuk mempengaruhi keputusan dari calon pelanggan maupun pelanggan sehingga terjadi pencapaian target pemasaran. Sendratari Ramayana Prambanan merupakan produk jasa hiburan yang merupakan satu satunya pertunjukan yang di pentaskan berlatar Candi Prambanan, berdasarkan jadwal pertunjukan yang sudah pasti, tempat (place) yang berada dikomplek Candi prambanan yang strategis dan mudah dijangkau. Dengan tersedia dua panggung pertunjukan terbuka (musim kemarau) dan tertutup (musim penghujan). Pementasan tersaji dalam dua cerita Dengan harga (price) yang dibedakan dalam beberapa kelas yaitu VIP, Khusus, Klas I, Klas II dan harga pelajar. Promosi (promotion) yang telah dilakukan oleh Sendratari Ramayana 
untuk lebih dikenal melalui berbagai media yaitu media cetak, media elektronik, sosialisasi dan melalui penjualan langsung, tentunya biaya promosi yang harus dikeluarkan oleh perusahaan tersebut sangat besar. Akan tetapi dengan promosi yang efektif dan efisien dengan target pasar yang tepat akan memberikan hasil yang maksimal, karena hal ini dapat meningkatkan jumlah kunjungan ke Sendratari Ramayana. Sehingga produk yang menarik dan berkualitas dengan harga yang terjangkau, tempat yang strategis dan mudah dijangkau didukung dengan promosi yang baik akan mempengaruhi keputusan pengunjung dalam menentukan pilihan atau keputusan pembelian untuk mengunjungi Sendratari Ramayana Prambanan di Prambanan.

Pengelola Sendratari Ramayana Prambanan telah melakukan usaha untuk mempromosikan produknya agar lebih dikenal dan diminati. Tentu diimbangi dengan peningkatan pelayanan dan sarana prasarana pendukung.

Sendratari Ramayana Prambanan selain usaha bisnis dalam mencari profit, juga mempunyai misi pelestarian warisan budaya yang harus tetap dijaga dan dilestarikan.

\section{Tujuan penelitian ini adalah sebagai berikut}

1. Untuk mengetahui pengaruh bauran pemasaran yang terdiri dari produk ( Product), arga (Price), Tempat (Place), dan Promosi (Promotion) secara parsial maupun stimultan terhadap keputusan wisatawan untuk mengunjungi Sendratari Ramayana Prambanan di Prambanan.

2. Untuk mengetahui diantara variabel bauran pemasaran yang terdiri dari produk (Product), Harga (Price), Tempat (Place), dan Promosi (Promotion) manakah yang paling dominan mempengaruhi keputusan wisatawan untuk mengunjungi Sendratari Ramayana Prambanan di Prambanan.

\section{PENELITIAN TERDAHULU}

Syahadat (2005) melakukan penelitian dengan judul Faktor - factor yang mempengaruhi kunjungan wisatawan di TNGP (Taman Nasional Gede Pangrango) Kajian hasil penelitian ini bertujuan untuk mengetahui besarnya pengaruh faktor - faktor tersebut secara bersama sama (simultan) terhadap jumlah pengunjung. Analisa data dilakukan dengan menggunakan metode analisis regresi linier berganda. Hasil penelitian menunjukkan bahwa faktor pelayanan, faktor sarana prasarana, factor objek dan daya tarik wisata alam, dan faktor keamanan secara simultan mempunyai pengaruh terhadap jumlah pengunjung akan tetapi secara nyata (tidak signifikan) di TNGP. Akan tetapi secara parsial, keempat faktor tersebut faktor keamanan yang mempunyai pengaruh yang signifikan (nyata) dan dominan terhadap jumlah pengunjung di TNGP.

Hasan (2012) melakukan penelitian dengan judul faktor-faktor yang mempengaruhi keputusan wisatawan Dalam melakukan kunjungan wisata di kota Tidore kepulauan Kajian hasil penelitian terdahulu yang di tulis oleh Husaen Hasan penelitian ini bertujuan untuk mengetahui Faktor marketing mix, social budaya, dan psikologis secara simultan dan parsial berpengaruh positif dan signifikan terhadap keputusan wisatawan dalam melakukan kunjungan wisata di Kota Tidore Kepulauan dengan menggunakan metode analisa regresi linear berganda.

Hasil Penelitian ini dapat disimpulkan bahwa Faktor marketing mix, sosial budaya, dan psikologis secara simultan dan parsial berpengaruh positif dan signifikan terhadap keputusan wisatawan dalam melakukan kunjungan wisata di Kota Tidore Kepulaun. Untuk pemerintah 
daerah, terutama Dinas Pariwisata sebagai pengelola obyek wisata Kota Tidore Kepulauan perlu memperhatikan faktor bauran pemasaran karena hasil penelitian ditemukan bahwa faktor bauran pemasaran adalah factor yang paling rendah nilainya berpengaruh terhadap keputusan wisatawan. Oleh karena itu, pemerintah agar lebih memfokuskan perhatian dalam perbaikan infrastruktur, sarana prasarana yang dibutuhkan oleh wisatawan, lebih meningkatkan strategi promosi, perbaikan sumber daya manusia, dan mampu memodifikasi produk-produk wisata yang ditawarkan kepada wisatawan. Sehingga mampu menarik wisatawan jumlah yang lebih banyak.

Yulia (2011) melakukan penelitian dengan judul Analisa Pengaruh Bauran Pemasaran Terhadap Keputusan Wisatawan asing Berlibur di Kota Semarang.

Kajian hasil penelitian untuk menganalisis faktor-faktor yang mempengaruhi keputusan wisatawan asing untuk berlibur di Kota Semarang, yang meliputi variabel produk, tempat, harga, dan promosi (marketing mix). Populasi dalam penelitian ini adalah wisatawan asing yang berada di Semarang. Teknik yang digunakan dalam pengambilan sampel dalam penelitian ini adalah nonprobability sampling dengan accidental sampling. Jumlah sampel yang diambil sebanyak 100 responden. Metode pengumpulan data dilakukan dengan membagi kuesioner kepada responden untuk diisi. Data yang diperoleh dianalisis dengan menggunakan program SPSS.

Hasil penelitian ini adalah variabel produk, harga, tempat, dan promosi (marketing mix) memiliki pengaruh positif dan signifikan terhadap keputusan wisatawan asing untuk berlibur ke Kota Semarang.

Sehingga produk, harga, tempat dan promosi merupakan faktor yang destinasi akan menjadi tujuan kunjungan.

Saputra (2011) melakukan penelitian dengan judul Analisis Pengaruh Bauran Pemasaran Terhadap Keputusan Wisatawan Asing Berlibur di Objek Wisata Gunung Bromo Jawa Timur Penelitian bertujuan untuk menganalisis pengaruh pengaruh produk, tempat, harga dan promosi secara simultan terhadap keputusan wisatawan asing berlibur di objek wisata Gunung Bromo Jawa Timur.

Teknik sampel yang dipergunakan adalah accidental sampling. Dalam penelitian ini yang menjadi populasi tidak diketahui dan jumlah sampel yang diambil sebanyak 100 orang. Teknik analisis yang dipergunakan adalah analisis regresi berganda. Hasil dari penelitian telah menunjukan bahwa secara simultan dan parsial variabel bauran penting dan berpengaruh positif dan signifikan yang menentukan sebuah pemasaran yang terdiri dari Produk (X1), Tempat (X2), Harga (X3) dan Promosi (X4) berpengaruh terhadap keputusan wisatawan asing berlibur di Objek wisata Gunung Bromo Jawa Timur.

Bauran Pemasaran

Kotler dan Keller (2009) juga menyatakan bahwa bauran pemasaran atau yang sering disebut sebagai Empat $\mathrm{P}$ dapat dilihat dari dua sudut pandang yaitu, sudut pandang penjual dan sudut pandang pembeli. Dari sudut pandang penjual, empat $\mathrm{P}$ merupakan perangkat pemasaran yang tersedia untuk mempengaruhi pembeli. Sedangkan, dari sudut pandang pembeli empat $P$ merupakan perangkat pemasaran yang dirancang untuk memberikan manfaat bagi pelanggan.

Komponen-komponen dari bauran pemasaran yang sering disebut empat $\mathrm{P}$ tersebut antara lain: Produk (produck), harga (price), tempat (place) dan promosi (promotion). 


\section{Produk (Product)}

Segala sesuatu yang dapat ditawarkan kedalam pasar untuk diperhatikan, dimiliki, dipakai, atau dikonsumsi sehingga dapat memuaskan suatu keinginan atau kebutuhan. Menurut Kotler dan Armstrong (2003), produk adalah segala sesuatu yang dapat ditawarkan ke pasar untuk mendapatkan perhatian, dibeli, dimiliki, digunakan, atau dikonsumsi yang dapat memuaskan keinginan atau kebutuhan pemakainya.

\section{Harga (Price)}

Menurut Kotler dan Amstrong (2008), harga adalah sejumlah uang yang ditagihkan atas suatu produk dan jasa atau jumlah dari nilai yang ditukarkan para pelanggan untuk memperoleh manfaat dari memiliki atau menggunakan suatu produk atau jasa.

Harga adalah unsur penting dalam sebuah peusahaan dimana dengan adanya harga maka perusahaan akan mendapatkan income bagi keberlangsungan perusahaan. Selain itu, harga juga merupakan alat yang nantinya dijadikan proses pertukaran terhadap suatu barang atau jasa oleh konsumen.

Perusahaan memilih metode penetapan harga yang mencakup satu atau lebih dari tiga pertimbangan ini. Menurut Kotler dan Keller (2009), ada enam metode penetapan harga, berikut penjelasannya :

a. Penetapan Harga Markup

Metode penetapan harga paling mendasar adalah menambah markup standar ke biaya produk. Sampai saat ini penetapan harga markup masih popular karena penjual dapat menentukan biaya jauh lebih mudah daripada memperkirakan permintaan, kemudian harga cenderung sama dan persaingan harga terminimalisasi ketika perusahaan dalam industri mengunakan metode ini, dan terakhir banyak orang merasa bahwa penetapan harga biaya plus lebih adil bagi pembeli dan penjual.

b. Penetapan harga tingkat pembelian sasaran

Perusahaan menentukan harga yang akan menghasilkan tingkat pengembalian atas investasi sasarannya.

c. Penetapan harga nilai anggapan

Nilai anggapan terdiri dari beberapa elemen seperti citra pembeli akan kinerja produk, kemampuan penghantaran dari saluran, kualitas jaminan, dukungan pelanggan, dan atribut

yang kurang dominan seperti reputasi pemasok, ketepercayaan dan harga diri.

d. Penetapan harga nilai

Metode yang menciptakan harga murah kepada konsumen untuk menarik perhatian konsumen dengan tidak mengabaikan kualitas produk perusahaan.

e. Penetapan harga going-rate

Perusahaan mendasarkan sebagian besar harganya pada harga pesaing, mengenakan harga yang sama, lebih mahal atau lebih murah dibandingkan harga pesaing utama.

f. Penetapan harga jenis lelang Penetapan harga jenis lelang dilakukan untuk membuang persediaan lebih atau barang bekas.

\section{Tempat (Place)}

Menurut Kotler (2005) Tempat (Place) termaksud berbagai aktivitas yang dilakukan perusahaan untuk membuta produk dapat di peroleh dan tersedia bagi pelanggan sasaran. Lokasi sering pula disebut sebagai saluran distribusi yaitu suatu perangkat organisasi yang 
saling tergantung dalam penyedia suatu produk atau jasa untuk digunakan atau dikonsumsi oleh konsumen atau pengguna bisnis. Sebelum produsen mamasarkan produknya, maka sudah ada perencanaan tentang pola distribusi yang akan dilakukan. Disini penting sekali perantara memiliki saluran distribusinya.

Peranannya ialah sangat penting karena dalam segala hal, merekalah yang berhubungan langsung dengan konsumen.

Lokasi terkait dimana perusahaan harus memilih lokasi, bermarkas serta melakukan operasi. Saluran distribusi merupakan organisasi - organisasi yang saling tergantung yang tercakup dalam proses yang membuat produksi atau jasa menjadi tersedia untuk digunakan atau dikonsumsi (Kotler:2007)

\section{Promosi (Promotion)}

Definisi promosi adalah kegiatan yang dilakukan oleh perusahaan untuk menonjolkan keistimewaan-keistimewaan produknya dan membujuk konsumen agar membelinya. Strategi promosi terdiri dari bermacam-macam komunikasi yang dilakukan untuk menyampaikan informasi dan meyakinkan atau membujuk calon wisatawan yang potensial untuk melakukan perjalanan wisata (Yoeti ,2005). Adapun macam kegiatan promosi yang biasa di lakukan adalah: Advertising, Personal Selling, Sales Promotions, Brochures Printing, Positioning, Public Relations, dan Publicity. Menurut Indrio Gitosudarmo (2007) berpendapat bahwa "bauran promosi yaitu kegiatan yang ditujukan untuk mempengaruhi onsumen agar mereka dapat menjadi kenal akan produk yang ditawarkan oleh pengusaha kepada mereka dan kemudian mereka menjadi senang lalu membeli produk tersebut".

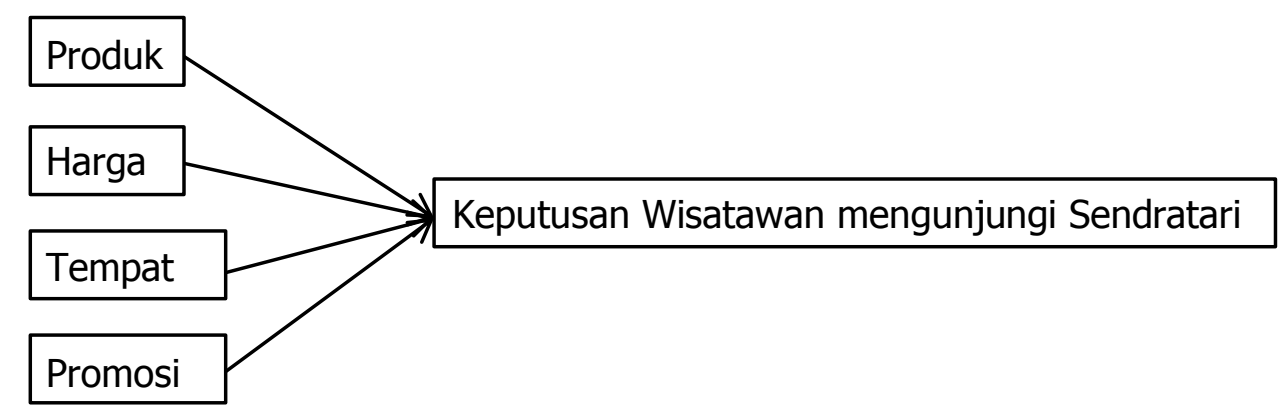

Gambar1. Model Penelitian

\section{METODE PENELITIAN}

\section{Lokasi Penelitian}

Penelitian ini dilakukan oleh penulis di PT Taman Wisata Candi Borobudur, Prambanan \& Ratu Boko (Persero) di Unit Teater \& Pentas yang terletak di Jalan Raya Jogja-Solo km. 16 Prambanan Yogyakarta.

\section{Sampel}

$N=\frac{(1,976) 2 \times(0,05) \times(0,5) 97,6}{(0,10) 2}=100$

Teknik sampling yang digunakan dalam penelitian menggunakan Teknik Probability Sampling. 
Teknik pengumpulan data, kuesioner, pengamatan, dan dokumentasi.

\section{Instrumen penelitian}

Adapun instrument penelitian aini adalah validitas, reliabilitas, uji asumsi klasik, regresi linear berganda, korelasi, koefosoen determinasi. Uji t, dan uji f.

\section{HASIL PENELITIAN}

\section{Uji validitas}

Tabel 1

Uji Validitas

\begin{tabular}{llllll}
\hline NO & Variabel & Indikator & KoefisienValiditas & rtable $(\mathrm{a}=0,05)$ & Keterangan \\
\hline 1 & Produk & X1.1 & 0,574 & 0,195 & Valid \\
2 & & X1.2 & 0,627 & 0,195 & Valid \\
3 & & X1.3 & 0,583 & 0,195 & Valid \\
4 & & X1.4 & 0,624 & 0,195 & Valid \\
5 & & X1.5 & 0,611 & 0,195 & Valid \\
1 & Harga & X2.1 & 0,591 & 0,195 & Valid \\
2 & & X2.2 & 0,629 & 0,195 & Valid \\
3 & & X2.3 & 0,641 & 0,195 & Valid \\
1 & Tempat & X3.1 & 0,792 & 0,195 & Valid \\
2 & & X3.2 & 0,773 & 0,195 & Valid \\
3 & & X3.3 & 0,779 & 0,195 & Valid \\
4 & & X3.4 & 0,498 & 0,195 & Valid \\
1 & Promosi & X4.1 & 0,624 & 0,195 & Valid \\
2 & & X4.2 & 0,821 & 0,195 & Valid \\
3 & & X4.3 & 0,767 & 0,195 & Valid \\
4 & & $X 4.4$ & 0,817 & 0,195 & Valid \\
1 & Keputusan & Y1.1 & 0,724 & 0,195 & Valid \\
2 & Wisatawan & Y1.2 & 0,738 & 0,195 & Valid \\
3 & & Y1.3 & 0,679 & 0,195 & Valid \\
4 & & Y1.4 & 0,567 & 0,195 & Valid \\
5 & Y1.5 & 0,675 & 0,195 & Valid \\
6 & & Y1.6 & 0,684 & 0,195 & Valid \\
\hline
\end{tabular}

Sumber hasil olah data SPSS, diolah 2015.

Hasil tabel diatas menujukan bahwa dari hasil uji validitas variabel produk, harga, tempat, promosi dan keputusan wisatawan bahwa nilai $r$ hitung indikator pertanyaan lebih besar $(>)$ dari $r$ tabel, yang berarti masing - masing indikator adalah valid. 


\section{Uji Realibilitas}

Tabel 2

Hasil Uji Reliabilitas pada variabel $X$ dan $Y$

\begin{tabular}{|c|c|c|}
\hline No Variabel & Koefisien Reabilitas & Keterangan \\
\hline 1 Produk (X1) & 0,734 & Reliabel \\
\hline 2 Harga (X2) & 0,712 & Reliabel \\
\hline 3 Tempat (X3) & 0,785 & Reliabel \\
\hline 4 Promosi (X4) & 0,801 & Reliabel \\
\hline 5 Keputusan Wisatawan (Y) & 0,769 & Reliabel \\
\hline
\end{tabular}

Sumber: Hasil Olah Data, diolah 2015.

Berdasarkan hasil pada tabel 2 menunjukkan bahwa variabel produk, harga, tempat, promosi dan keputusan wisatawan memiliki cronbach's alpha lebih besar dari 0,06 yang berarti realibel.

\section{Uji Asumsi Klasik}

Uji asumsi klasik berupa normalitas, autokorelasi, multikoliearitas, heteroskedastisitas, secara keseluruhan tidak mengandung gejala asumsi klasik.

\section{Analisa Regresi Linear Berganda}

Analisis Linear berganda digunakan untuk mengetahui pengaruh bauran pemasaran (produk, harga, tempat dan promosi) terhadap keputusan wisatawan. Dengan analisa ini juga dapat diketahui variabel yang berpengaruh terhadap keputusan wisatawan baik secara simultan maupun parsial.

Persamaan umum regresi linear berganda adalah sebagai berikut :

$$
Y=a+b 1 X 1+b 2 X 2+b 3 X 3+b 4 X 4
$$

Tabel 3

Analisa Regresi Linear Berganda

Coefficients $^{a}$

\begin{tabular}{|c|c|c|c|c|c|}
\hline \multirow[t]{2}{*}{ Model } & \multicolumn{2}{|c|}{ Unstandardized Coefficients } & \multirow{2}{*}{$\begin{array}{c}\text { Standardized Coefficients } \\
\text { Beta }\end{array}$} & \multirow[b]{2}{*}{$\mathrm{t}$} & \multirow[b]{2}{*}{ Sig. } \\
\hline & $\mathrm{B}$ & Std.Error & & & \\
\hline (Constant) & 1,544 & 3,501 & & 441 & 660 \\
\hline $\mathrm{X} 1$ & ,346 & 127 & ,214 & 2,727 & ,008 \\
\hline $\mathrm{X} 2$ &,- 114 & 218 &,- 037 &,- 522 & 603 \\
\hline $\mathrm{X} 3$ & ,491 & 138 & ,319 & 3,549 & ,001 \\
\hline $\mathrm{X} 4$ &, 515 & ,122 & ,375 & 4,239 &, 000 \\
\hline
\end{tabular}

a. Dependent Variable: Y

$$
Y=1,544+0,346 \times 1+-0,114 \times 2+0,491 \times 3+0,515 \times 4
$$

Dapat diketahui besarnya kontribusi variabel bebas terhadap variabel terikat antara lain: X1 : 0,346 artinya apabila penilaian terhadap variabel produk meningkat sebesar satu satuan, maka penilaian terhadap keputusan wisatawan akan meningkat sebesar 0,346 satuan. 
X2 : -0,114 artinya apanila penilaian terhadap penilaian variabel harga meningkat sebesar satu satuan, maka penilaian terhadap keputusan wisatawan akan menurun sebesar 0,114 satuan.

X3 : 0,491 artinya apabila penilaian terhadap variabel tempat meningkat sebesar satu satuan, maka penilaian terhadap keputusanwisatawan akan meningkat sebesar 0,491 satuan.

X4 : 0,515 artinya apabila penilaian terhadap variabel promosi meningkat sebesar satu satuan, maka penilaian terhadap keputusan wisatawan akan meningkat sebesar 0,515 satuan.

Sehingga dapat disimpulkan bahwa produk ( $x 1)$, tempat $(x 3)$ dan promosi $(x 4)$ arah hubungan positif terhadap keputusan wisatawan. Dengan kata lain apabila penilaian terhadap variabel produk (x1), tempat (x3) dan promosi (x4) meningkat maka akan diikuti peningkatan penilaian terhadap variabel keputusan wisatawan. Harga (x2) tidak ada arah positif terhadap keputusan wisatawan. Sehingga dengan kata lain apabila penilaian terhadap variabel harga (x2) meningkat maka akan diikuti penurunan penilaian terhadap variabel keputusan wisatawan

\section{Uji t-student}

T test antara produk (X1) dengan $Y$ (keputusan wisatawan) menunjukkan t hitung 2,727. Sedangkan t tabel (a: $0.05 ; \mathrm{db}$ residual $=95$ ) adalah 1,985 . Karena $\mathrm{t}$ hitung $>\mathrm{t}$ tabel yaitu 2,727 > 1,985 atau sig 0,008 < 0,05 maka pengaruh produk (X1) terhadap keputusan wisatawan signifikan / berpengaruh.

T test antara harga (X2) dengan $Y$ (keputusan wisatawan) menunjukkan t hitung $-0,522$. Sedangkan t tabel (a: 0.05; db residual $=95$ ) adalah 1,985. Karena $t$ hitung $<\mathrm{t}$ tabel yaitu $522<1,985$ atau sig 0,603 > 0,05 maka pengaruh harga (X2) terhadap keputusan wisatawan tidak signifikan / tidak berpengaruh.

T test antara tempat (X3) dengan $Y$ (keputusan wisatawan) menunjukkan t hitung 3,549. Sedangkan $\mathrm{t}$ tabel $(\mathrm{a}: 0.05 ; \mathrm{db}$ residual $=95$ ) adalah 1,985. Karena $\mathrm{t}$ hitung $>\mathrm{t}$ tabel yaitu 3,549>1,985 atau sig 0,001 < 0,05 maka pengaruh tempat (X3) terhadap keputusan wisatawan signifikan / berpengaruh.

T test antara promosi (X4) dengan $\mathrm{Y}$ (keputusan wisatawan) menunjukkan t hitung 4,239. Sedangkan t tabel (a: 0.05; db residual $=95$ ) adalah 1,985 . Karena $t$ hitung $>t$ tabel yaitu 4,239< 1,985 atau sig 0,000 < 0,05 maka pengaruh promosi (X4) terhadap keputusan wisatawan signifikan / berpengaruh.

\section{PEMBAHASAN HASIL PENELITIAN}

Hasil penelitian menunjukkan bahwa variabel produk, harga, tempat dan promosi berpengaruh positif dan signifikan terhadap keputusan wisatawan untuk mengunjungi

Sendratari Ramayana Prambanan di Prambanan. Untuk lebih jelasnya berikut pembahasannya :

\section{Pengaruh produk terhadap keputusan wisatawan}

Variabel produk mempunyai pengaruh positif dan signifikan terhadap keputusan wisatawan. Berdasarkan deskripsi penilaian variabel produk berada pada kategori sangat baik. Hal ini merupakan modal utama karena produk adalah pertujukan Sendratari Ramayana yang merupakan pertunjukan kolosal sebuah warisan budaya bangsa. Yang sudah mendunia dan harus tetap dilestarikan. Namun berjalannya waktu semakin banyak pesaing berupa 
pertunjukan serupa yang dipentaskan di hotel, tempat pertunjukan lain di Yogyakarta yang berada lebih dekat di pusat kota. Sehingga harus tetap menjaga kwalitas pertunjukan dalam menghadapi persaingan yang ada agar tetap bertahan. Penelitian ini sejalan dengan penelitian Bayu (2012) dimana variabel produk berpengaruh positif pada keputusan wisatawan untuk berkunjung pada Objek Bukit Cinta Ambarawa.

\section{Pengaruh harga terhadap keputusan wisatawan}

Berdasarkan hasil Hasil t test antara harga (X2) dengan $\mathrm{Y}$ (keputusan wisatawan) menunjukkan pengaruh harga (X2) terhadap keputusan wisatawan tidak signifikan / tidak berpengaruh. Dan hasil analisa linear berganda juga menunjukkan arah hubungan tidak positif terhadap keputusan wisatawan. Harga berpengaruh negatif terhadap keputusan brkunjung, hal ini sesuai pendapat (Tjiptono, 2005) yaitu jika harga tidak terjangkau oleh para pembeli sasarannya, maka produk tidak akan terserap pasar. Price (harga) adalah biaya, waktu, dan usaha yang konsumen keluarkan atau bayarkan untuk menikmati maupun membeli produk yang dijual maupun layanan yang perusahaan tawarkan atau sajikan. Harga tiket masuk untuk meyaksikan Sendratari Ramayana Prambanan bervariasi terdapat beberapa kelas yang disesuaikan dengan fasilitas dan posisi tempat duduk. Untuk mengapresiasi sebuah karya seni adalah bukan hal yang mudah. Dan ini sangat relatif tergantung penikmatnya. Sehingga ada yang merasakan bahwa harga tiket Sendratari Ramayana mahal, hal ini karena mereka mempunyai pembanding pertunjukan serupa yang lebih murah. Penlitian ini sejalan dengan hasil penelitian Anjar (2011) bahwa harga berpengaruh negatif pada keputusan wisatawan untuk berkunjung.

\section{Pengaruh tempat terhadap keputusan wisatawan}

Variabel tempat pada hasil penelitian ini berpengaruh positif dan sinifikan terhadap keputusan wisatawan. Hal ini ditunjukkan oleh hasil deskripsi variabel tempat berada pada kategori baik. Tempat adalah keputusan manajemen mengenai kapan, dimana, dan bagaimana menyajikan layanan yang baik kepada pelanggan. Tempat atau lokasi pertunjukan Sendratari Ramayana Prambanan merupakan tempat yang strategis dan merupakan tempat pertunjukan satu - satunya yang berlatar belakang kemegahan Candi Prambanan. Akses menuju tempat pertunjukan juga sangat mudah diakses. Sehingga tempat merupakan variabel yang mempengaruhi keputusan wisatawan dalam memutuskan untuk menyaksikan Pertunjukan Sendratari Ramayana Prambanan. Penelitian ini sejalan dengan penelitian Yulia (2011) dimana tempat berpengaruh terhadap keputusan berkunjung.

\section{Pengaruh promosi terhadap keputusan wisatawan}

Hasil $t$ test antara promosi ( $X 4$ ) dengan $Y$ (keputusan wisatawan) menunjukkan berpengaruh positif dan signifikan terhadap keputusan wisatawan.

Promosi dilakukan oleh perusahaan untuk mengenalkan, menawarkan produk agar dapat diminati dan dengan tujuan dapat mempengaruhi konsumen agar memutuskan untuk membeli atau menikmatinya. Untuk lebih mengenalkan dan menjaga warisan budaya pihak Sendratari Ramayana prambanan mempromosikan produknya dengan berbagai cara, baik melalui media cetak maupun media sosial. Dengan sasaran dalam dan luar negeri, sesuai pangsa pasar yang telah ditentukan sesuai target pasar akan di capai.

Berdasarkan hasil penelitian variabel produk, harga, tempat dan promosi secara simultan mempunyai pengaruh positif dan signifikan terhadap keputusan wisatawan. Hal tersebut 
ditunjukkan bahwa variabel produk, harga, tempat dan promosi berpengaruh positif dan kuat terhadapkeputusan wisatawan. Besarnya pengaruh secara simultan sebesar 52,5\% sedangkan sisanya 47,5 \% dipengaruhi variabel lain diluar penelitian ini.

\section{KESIMPULAN}

Berdasarkan hasil penelitian, maka dapat ditarik kesimpulan sebagai berikut :

1. Terdapat pengaruh secara parsial antara bauran pemasaran yang terdiri dari produk, harga, tempat dan promosi terhadap keputusan wisatawan untuk mengunjungi Sendratari Ramayana Prambanan.

2. Terdapat pengaruh secara simultan pada variabel produk, harga, tempat dan promosi terhadap keputusan wisatawan mengunjungi Sendratari Ramayana Prambanan.

3. Variabel promosi berpengaruh paling dominan terhadap keputusan wisatawan untuk mengunjungi Sendratari Ramayana Pramabanan.

\section{SARAN}

Berdasarkan kesimpulan di atas, selanjutnya dapat diusulkan saran yang diharapkan akan bermanfaat bagi pengelola Sendratari Ramayana Prambanan untuk lebih memberikan pelayanan dan pertunjukan yang berkualitas untuk mempengaruhi wisatawan agar menyaksikan Sendratari Ramayana Prambanan.

1. Pagelaran Sendratari Ramayana Prambanan merupakan produk sekaligus sebagai warisan budaya dunia yang adiluhung dan harus dilestarikan, sehingga harus profesional, konsisten dan menciptakan inovasi baru untuk menarik wisatawan untuk memenangkan persaingan.

2. Harga merupakan rangkaian dari sebuah produk. Dalam penentuan harga haruslah tetap dikaji dan dievaluasi apakah sudah sesuai dengan fasilitas yang diberikan, sesuai dengan kualitas pertunjukan yang disajikan.

3. Tempat merupakan hal penting karena merupakan dimana menyajikan layanan yang ditawarkan. Tempat pertunjukan Sendratari Ramayana Prambanan merupakan tempat yang strategis dan mudah diakses. Untuk lebih memberikan kemudahan akses untuk mencapainya diharapkan penambahan signal penunjuk arah untuk menuju tempat ini ditambah. Memberikan keamanan di lokasi, keasrian serta kebersihan sarana prasarana akan menambah daya tarik pada pertunjukan ini

4. Promosi pada Sendratari Ramayana Prambanan selayaknya untuk ditingkatkan dalam menghadapi persaingan yang ada. Mengevaluasi setiap media maupun sarana prasarana yang digunakan dalam promosi. Apakah sudah sesuai dan mengena pada target pasar yang dituju. Setiap informasi yang ada, hal - hal yang baru untuk selalu diupdate kepada konsumen. Membidik media promosi yang sedang trend di pasar sehingga semakin mudah untuk mendapatkan informasi tentang Sendratari Ramayana Prambanan. Lebih aktif menjalin hubungan dengan pelaku wisata, travel agent, hotel, restaurant serta instansi - instansi terkait dalam bersinergi mempromosikan produk yang ada.

5. Bagi peneliti selanjutnya hendaknya memperluas variabel penelitian yang dapat mempengaruhi keputusan wisawan misalnya menambah people, distribusi dan lain - lain

\section{DAFTAR PUSTAKA}

Budiyono, 2009. Statistika untuk Penelitian: Sebelas Maret University Press. 
Daniel Tanjung Saputro, 2011: Analisis Pengaruh Bauran Pemasaran Terhadap Keputusan Wisatawan Asing Berlibur Di Objek Wisata Gunung Bromo Jawa Timur, Fakultas IImu Sosial Dan Ilmu Politik UPN Veteran Jatim.

Kotler, Philip dan Kevin Lane Keller, 2008: Manajemen Pemasaran (Edisi Ketiga Belas), PT. Indeks, Jakarta.

Kotler, Philip dan Kevin Lane Keller, 2005: Manajemen Pemasaran, PT. Indeks, Jakarta, Kotler,2007 : Manajemen Pemasaran

Drs. Moehkardi, 2011. Sendratari Ramayana Prambanan Seni dan Sejarahnya, KPG (Kepustakaan Populer Gramedia)

Mangkunegara, A.P, 2009 : Perilaku Konsumen, Edisi Revisi, Cetakan Keempat, (Bandung:PT Refika Aditama).

Sinaga, Obsatar, 2010 : Implementasi ASEAN Free Trade Agreement di Jawa Barat, Bandung : Lepsindo.

Sunyoto, Danang, 2011 : Metodologi Penelitian untuk Ekonomi. Yogyakarta:CAPS (Center of Academic Publishing Service).

Oka A. Yoeti, 2005 : Perencanaan Strategis Pemasaran Daerah Tujuan Wisata Jakarta,Pradaya Paramita

Philip Kotler \& Kevin Lane Keller, 2009 : Manajemen pemasaran, Edisi 13 Jilid 1. Jakarta.

Philip Kotler, Kevin Lane Keller, 2008 : Manajemen Pemasaran, Edisi 13 Jilid 1, Alih Bahasa, Bob Sabran, (Erlangga: Jakarta)

Yulia Endah Sukma Purnamasari, 2011 :Analisis Pengaruh Bauran Pemasaran terhadap Keputusan Wisatawan Asing Berlibur Di Kota Semarang, Program Sarjana Fakultas Ekonomi Universitas Diponegoro Semarang 